\title{
Analysis of Masterplan in Medan City Determining the Strategic Area (KSK) Social Culture Fields in Medan
}

\author{
Jehan Ridho Izharsyah ${ }^{1}$, Faizal Hamzah Lubis ${ }^{2}$ \\ ${ }^{1,2}$ Faculty of Social Science and Political Science, Universitas Muhammadiyah Sumatera Utara, Indonesia \\ Jehanridho@umsu.ac.id
}

\section{Abstract}

The City Strategic Area (KSK) is a strategic area compiled by the City in developing the area as seen from aspects of the Economy, Social Culture, the environment and others. Medan City Government through the Regional Planning and Development Agency of Medan City Establishes several Strategic Areas in Medan City through the 2016-2021 Regional Spatial Plan (RTRW) of Medan City including the Social and Cultural Strategic Area (KSK). This study uses a research method with a qualitative descriptive approach.Among them are Identification of Potential and Problems, Program Identification and using P3 (Arrangement, Supervision and Coaching). The research results show that the Medan City Government has implemented P3 through the elaboration of the RTRW trip that has been running for 4 years. However, it is still constrained by the process of guidance and supervision. Because some of these regional assets are not fully owned by the City Government but are owned by tribes and companies. Based on SWOT analysis Strength 1.26 while weakness factor 1.23 and Opportunity with a total score of 1.84 while Challenge 1.85, then the placement of cartesius diagrams of several Strategic Cities that are the locations of research are in Diversification Strategy which means the City Strategic Area Supervision (SCC) has the potential to be developed but still some need to be prepared strategically and improve management by the Medan City Government
Keywords

spatial planning, strategic areas, $\mathrm{PB}$ (regulation, supervision and guidance)

\section{Introduction}

The City Strategic Area (KSK) is a strategic area prepared by the City in developing its territory as seen from the aspects of the Economy, Socio-Culture, the environment and others. Strategic Area is an area in which activities that have a major influence on: Spatial planning in the surrounding area, other activities in similar fields and activities in other fields and improving community welfare take place.

Therefore the City Strategic Area (KSK) is part of the Regional Spatial Plan (RTRW) in which there is a plan for the structure of the city area space. The urban spatial structure plan is a system framework of service centers for urban activities that are hierarchical and connected to each other by a city area infrastructure network system. Urban Spatial Structure Plan is a plan that includes the urban system of the city area.

There are several actual issues that occur in several cities in Indonesia, including: Social Issues (Decreased Quality of Life / Social, Urban Decay, Sprawling, etc.), economy (Low competitiveness deficit and others). Therefore the central government has explained several urban strategic issues including: 
1. National Issues

Which become urban strategic issues in the National aspect such as: High levels of urbanization, high disparities between cities and growth centers in Western Indonesia with cities in Eastern Indonesia.

2. Urban Issues in Indonesia

The concept of urban farming has become popular in many cities in the world. Urban farming is considered a means of promoting public health and economic development, building social capital, and reusing vacant land in urban areas (Bo'do, et al (2019).

Urban issues in Indonesia, such as: The minimum service standards for cities, high urban poverty, low urban competitiveness and low social, economic and environmental resilience in cities in a sustainable manner and low capacity for mitigating natural disasters and adapting to climate change spaces include:

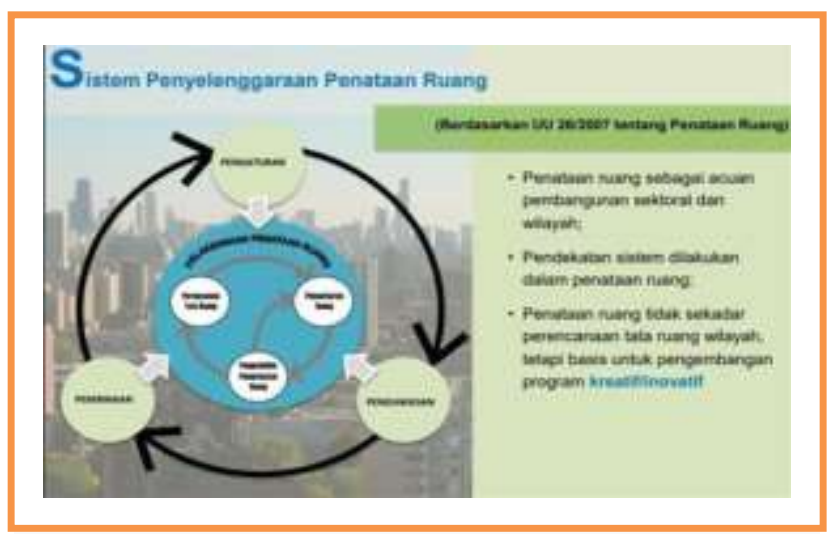

Figure 1. Spatial Planning Management System

With the picture above, Undang-Undang Nomor 26 Tahun 2007 concerning Spatial Planning has a system of Regulations, Supervision and Development later in its implementation there is a process of planning, exploiting and controlling spatial use. The law is poured into the Vision and Mission of National Urban Development, so that the vision is "The realization of a city that is livable, just, independent, and competitive in a sustainable manner for the welfare of urban communities, in accordance with the character of the local potential and culture in 2025. The mission of National Urban Development includes:

1. Equitable Development of Cities according to their function.

2. Development of a productive, attractive, efficient city economy by utilizing superior potential

3. Develop urban facilities and infrastructure that meet the Urban Service Standards (SPP) and promote social and cultural development of the community

4. Improve the quality of city government governance administrators.

With this vision and mission, the Medan City Government through the Medan City Regional Planning and Development Agency has established several strategic areas in Medan City through the 2016-2021 Regional Spatial Plan (RTRW) of Medan City, including:

1. Economic Strategic Areas

2. Strategic Areas in the Socio-Cultural Sector

3. Strategic Areas of Environmental Functions and Supporting Capacity, and

4. National Strategic Friends and Provincial Strategic Areas within the City of Medan.

Therefore, in accordance with the above discussion, the Medan City Government has prepared a strategic area in the Socio-Cultural Sector. According to the Spatial Planning and 
Strategic Areas Areas, in terms of social and cultural interests, among others: Certain customary areas, conservation areas for cultural heritage, including cultural heritage that is recognized as world heritage. The areas in Medan that are categorized as strategic sociocultural areas are: Polonia area, Labuhan Deli Old Town area, housing and warehousing area which was originally DSM, Maimun Palace area, Keling Village area and Kesawan area.

The importance of Regulation, Supervision and Guidance in the implementation and planning of the spatial system in Medan, especially planning in the aspects of the City Strategic Area (KSK). Therefore, the spatial planning system becomes a benchmark in addition to Medan City, which is one of the largest cities in Indonesia. The City Strategic Area is an indicator in increasing regional income through Regional Original Income. Therefore, the plan must also have strength, especially in determining the strategic location of the city. With the planning that has been prepared by the Medan City government regarding strategic areas in the socio-cultural sector. Therefore, the researcher wants to see how the Medan city Masterplan determines the City Strategic Area (KSK) in the socio-cultural field in Medan city seen in terms of: Regulation, Supervision and guidance.

\section{Review of Literatures}

\subsection{Spatial}

According to D.A. Tisnaadmidjaja, what is meant by space is "the physical form of a region in geographic and geometric dimensions which is a place for humans to carry out their life activities in a decent quality of life".

Spatial layout is a form of spatial structure and spatial patterns. Spatial structure is an arrangement of settlement centers and a network system of infrastructure and facilities that functions as a support for community socio-economic activities which hierarchically have functional relationships. Spatial planning is a system of spatial planning process, spatial use utilization and spatial use control.

\subsection{Spatial Planning Principles}

Based on Article 2 of Undang-undang tahun 2007, it is stated that spatial planning is carried out based on the principles of:

1. Cohesiveness

Integrity means that spatial planning is carried out by integrating various interests that are cross-sector, cross-regional and cross-stakeholder. The stakeholders include, among others, the government, local governments and the community.

2. Sustainability

Sustainability is that spatial planning is carried out by ensuring the preservation and continuity of the carrying capacity and carrying capacity of the environment by taking into account the interests of future generations.

3. Usefulness and efficiency

Usefulness and efficiency is that spatial planning is carried out by optimizing the benefits of space and resources contained in it and ensuring the creation of a quality spatial layout.

4. Openness

Openness is that spatial planning is carried out by providing the widest possible access to the public to obtain information related to spatial planning.

5. Togetherness and partnership

Togetherness and partnership is that spatial planning is organized by involving all stakeholders. 
6. Protection of public interest

Protection of the public interest is that spatial planning is carried out by prioritizing the interests of the community.

7. Legal certainty and justice

Legal certainty and justice is that spatial planning is carried out on the basis of law / provisions of statutory regulations and that spatial planning is carried out by considering the sense of justice of the community and protecting the rights and obligations of all parties fairly with a guarantee of legal certainty.

8. Accountability

Accountability is spatial planning that can be accounted for both the process, the financing and the results.

\subsection{Government / Local Government Duties and Authorities in Spatial Planning}

The state's duties in spatial planning include two things, namely; (a) police making, is determining the direction of the state; (b) task executing, namely the implementation of tasks according to the direction determined by the state. Carrying out the tasks referred to above, the state gives the government and regional governments the authority to organize spatial planning. The spatial planning arrangement is carried out while respecting the rights of people in accordance with the provisions of laws and regulations. Government authorities in spatial planning include:

1. Regulating, fostering and supervising the implementation of spatial planning for national, provincial and district / city territories, as well as for the implementation of spatial planning for national, provincial and district / city strategic areas.

2. Implementation of national territory spatial planning.

3. Implementation of national strategic area spatial planning.

Cooperation in spatial planning between countries and facilitating cooperation in spatial planning between provinces.

District/city regional government authorities in spatial planning management include:

1. Regulation, guidance and supervision of the implementation of spatial planning for regency / municipal areas and district / city strategic areas.

2. Implementation of district / city spatial planning.

3. Implementation of district / city strategic area spatial planning.

4. Cooperation in spatial planning between districts / cities.

The authority of the regency / city regional government in implementing spatial planning for regency / municipal areas as referred to in paragraph (1) letter b includes:

District / city spatial planning.

1. Utilization of district / city territory space.

2. Control of regency / municipal spatial use.

\subsection{Spatial Planning Implementation System}

Based on Undang-undang Nomor 26 Tahun 2007 concerning Spatial Planning that Spatial Planning As:

1. Spatial planning as a reference for sectoral and regional development

2. Systems approach is carried out in spatial planning

3. Spatial planning is not just regional spatial planning, but a basis for innovative programs. 


\subsection{Strategic Area Designation}

Based on the 2010-2030 Medan City Spatial Planning (RTRW) Strategic area is an area in which activities that have a major influence on:

1. Spatial layout in the surrounding area

2. Other activities in similar fields and activities in other fields: and / or

3. Improvement of community welfare.

Based on the types of strategic areas in Chapter VI RTRW for Medan City 2010-2030, Medan divides the types of strategic areas including:

\section{a. Strategic Areas of Economic Growth}

Strategic areas from the point of view of the interests of economic growth include metropolitan areas, special economic areas, integrated economic development areas, underdeveloped areas, trade areas and free ports.

\section{b. Strategic Areas in the Socio-Cultural Sector}

Strategic areas from the point of view of social and cultural interests include certain customary areas, conservation areas for cultural heritage, including cultural heritage that is recognized as world heritage.

c. Strategic area from the point of view of the function and carrying capacity of the Environment

Strategic areas from the point of view of environmental function and carrying capacity, include environmental protection and preservation areas, including areas recognized as world heritage such as National Parks. Protected area criteria strategic are:

1. Have an ecological role and save the environment and anticipate flood disasters

2. Has a high economic role if it can be managed properly

3. The need for city identity with plant development.

\section{d. National Strategic Areas and Provincial Strategic Areas}

The Medan City spatial plan also accommodates national and provincial strategic areas that play an important role and prioritize their development. The following are national strategic areas and provincial strategic areas within the city of Medan:

1. The National Strategic Area (KSN) in the city of Medan is the Mebidangro Urban Area.

2. The Provincial Strategic Area (KSP) in the Deli Serdang Regency is the Mainstay Area of Mebidangro Urban.

3. The National Strategic Area from the point of view of the interests of defense and security which is intended for the interests of national maintenance and defense based on the national geosrategic area contained in the City of Medan is (Air Base) Lanud Polonia in Medan Polonia District, Belawan Navy Base (Lanal) in Medan Belawan District Kodam in Medan Helvetia District. 


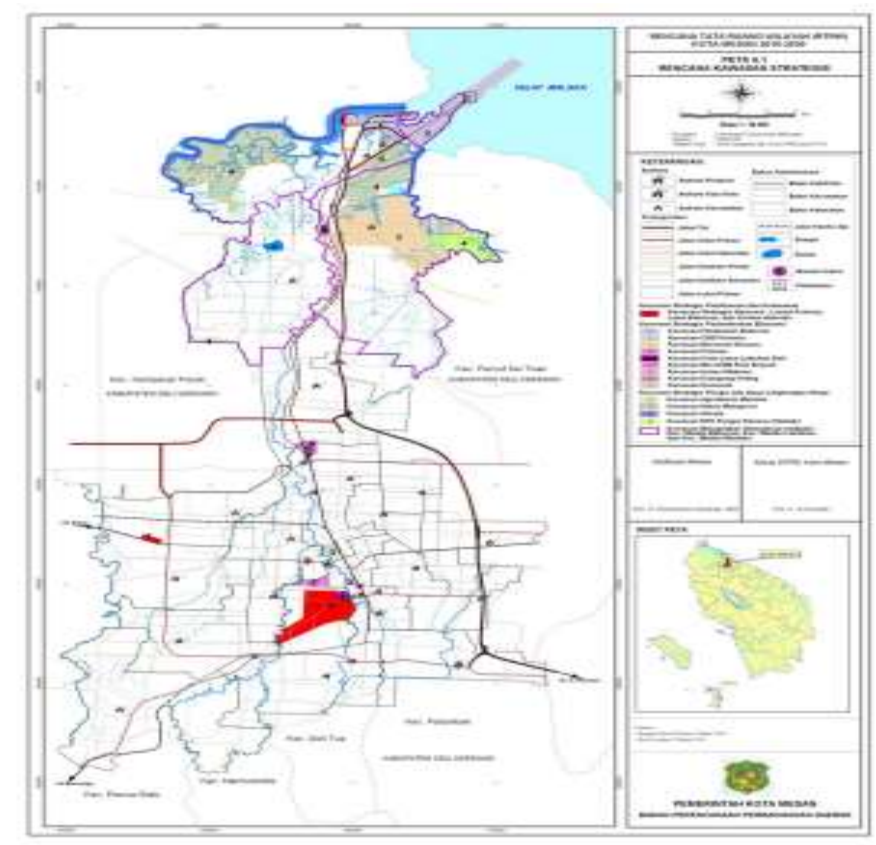

Figure 2. Map of Location Distribution of Strategic Areas in Medan City

\section{Research Methods}

This study uses a research method with a qualitative descriptive approach. Among them are Identification of Potentials and Problems, Identification of Programs and using P3 (Regulation, Supervision and Guidance). The research was conducted with field studies, interviews and documentation with several interest groups such as: Bappeda and visits to several strategic areas in Medan City. The analysis technique used was purposive sampling and SWOT.

\section{Results and Discussion}

\subsection{The Process of Arranging City Strategic Areas (KSK) in the Socio-Cultural Sector in Medan City}

The Effort to arrange this Area, the Medan City Government has designed several policies including:

1. Spatial Structure Development Policy

The policy for the development of the urban spatial structure is the expected arrangement of the elements forming the natural environment, the social environment, and the strategic artificial environment for the City of Socio-Culture in Medan City. The Medan City Government has a strategy to improve the quality of structuring, including a strategy to improve the quality and range of service network infrastructure for transportation, telecommunications, energy, water resources, and urban infrastructure and facilities that are integrated and evenly distributed throughout the region. For example, Regulations on Quality Improvement, Reach and Integrity.

Quality, reach and integration are basic things that the Medan City government must pay attention to in the spatial structuring process. Especially improving the quality of the road network, transportation and others that support the quality of speed and motion on main roads and arteries. 
And then, the reach in the meaning that is considered is how people and the tourism community can access strategic areas well, safely and comfortably. This creates a sense of satisfaction if access to the location and area development can be reached properly. Delango (2019) stated that for the rural people, in the short run it may help to alleviate the poverty by creating new income and employment opportunity and it has helped in facilitating rural-urban economic and social integration and motivating the expansion of the urban sector. Meanwhile, integration is the existence of good, safe and comfortable transportation access in accordance with the motto of Medan City to the location of the protected area.

In the meaning of the public can use the accessibility of transportation, good and affordable roads with location. In the process of developing the Medan City Strategic Area (KSK), there are several things that need to be considered, including:

1. Supporting the functioning of settlement service centers In order to support the functioning of settlement service centers, it is necessary to increase the connection power between parts of the city area which forms an integrated pattern. The pattern includes Strategic Areas which are integrated directly into residential areas which are considered comfortable, safe and conducive.

2. Support the functioning of service centers for settlements, workplaces, schools and other public facilities. In this case to increase the good convenience to strategic locations. $\varpi$ Construction of new roads as well as upgrading of old roads will still prioritize direction of service centers and development with consideration of traffic volume and existing road network patterns. In this discussion, road access to areas that have been planned in the Medan City master plan should also be prioritized.

Then, the arrangement that should be considered in supporting the Strategic Area is the improvement of transportation facilities and infrastructure. What is no less important in structuring and developing the transportation system is transportation infrastructure and facilities to support the success of the overall system. So to support the success of structuring the city's strategic area, improvement of infrastructure and facilities is also supportive. Then the development process includes:

1. Improve transportation infrastructure by repairing and equipping main and supporting infrastructure.

2. Efficiency of movement is carried out by limiting the operating area of each mode of public transport according to its characteristics. In turn, this will optimize the potential of each mode and provide convenience for the community with alternative convenience in choosing the mode of transportation.

3. Improvement of regional passenger terminals that serve buses and city transportation.

4. Integrate railway terminals and stations (mass transit) with trade, service and settlement centers.

5. Maintain existing train stations as passenger terminals and developing a new station for loading and unloading goods whose location is integrated with the bus terminal, container terminal (dry port), freight terminal and warehouse areas in the northern part of the city (Medan Labuhan and Belawan Districts).

6. Development of a mass transportation system to support Medan City as a Metropolitan City, which includes bus lines, busways, monorails, LRT or heavy rail.

7. Development of the port of Belawan as a port of international relations.

8. Development of a passenger port (TOD) integrated with a railway station and warehousing, international container seaports, industrial estates, warehousing and expedition, Export Processing Zone (EPZ) and residential centers

9. Development of the former Polonia Airport area as a Central Business District (CBD). 
10. Provision of parking space by linking it to a building permit (IMB) application. For each type of building use, certain parking area requirements are imposed, especially for downtown areas.

11. Development of off-street parking systems and on-street parking arrangements and restrictions.

\subsection{The Process of City Strategic Area Development (KSK) in the Field of Socio-Culture in Medan City}

Based on the definition that has been compiled by the Medan City Government in the RTRW, it is a certain customary area, a cultural heritage conservation area, including cultural heritage that is recognized as world heritage Regions

1. Polonia Region

The Polonia area is one of the strategic areas planned by the Medan City Government in the RTRW. Development of the former Polonia Airport area as a Central Business District (CBD). In this case the government has arranged The Polonia Masterplan as a business area for the Medan City Government (Pemko) has designated the Soewondo Airfield area as the Central Business District (CBD), after Polonia Airport was moved to Deliserdang Regency, which is now Kualanamu Airport (Kualanamu International Airport / KIA. This has been included in the RDTR Regional Regulation. 2014 - 2034 which was passed during the period March 2014.
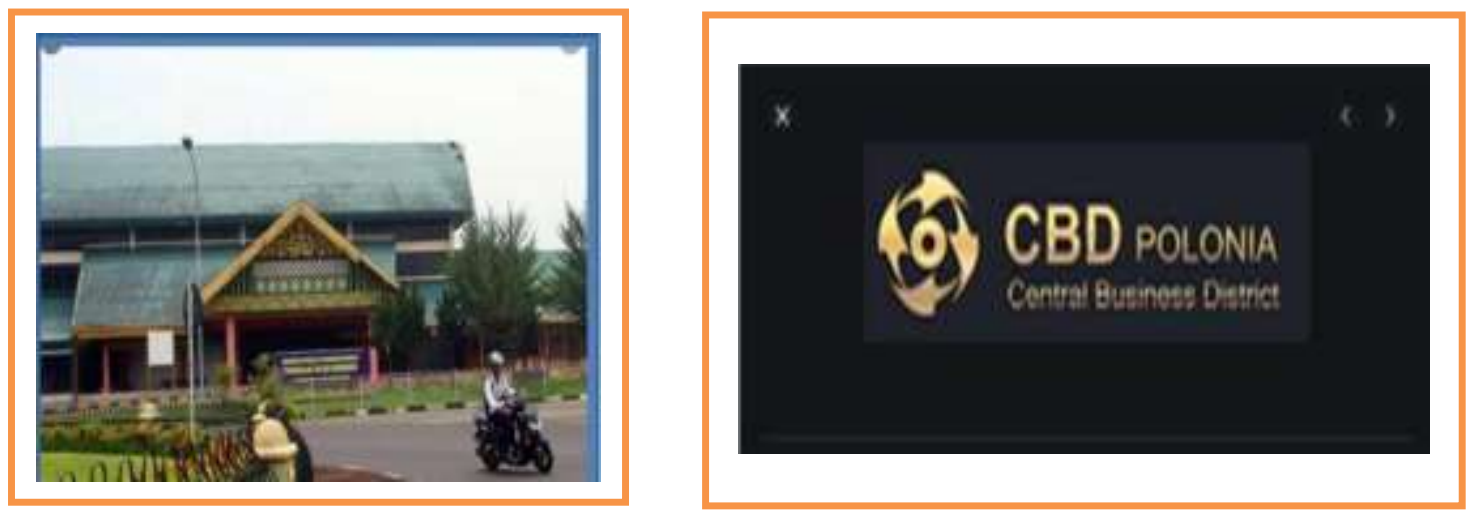

Figure 3. Former Polonia Airport Becomes CBD Polonia

2. Tri Dharma Temple

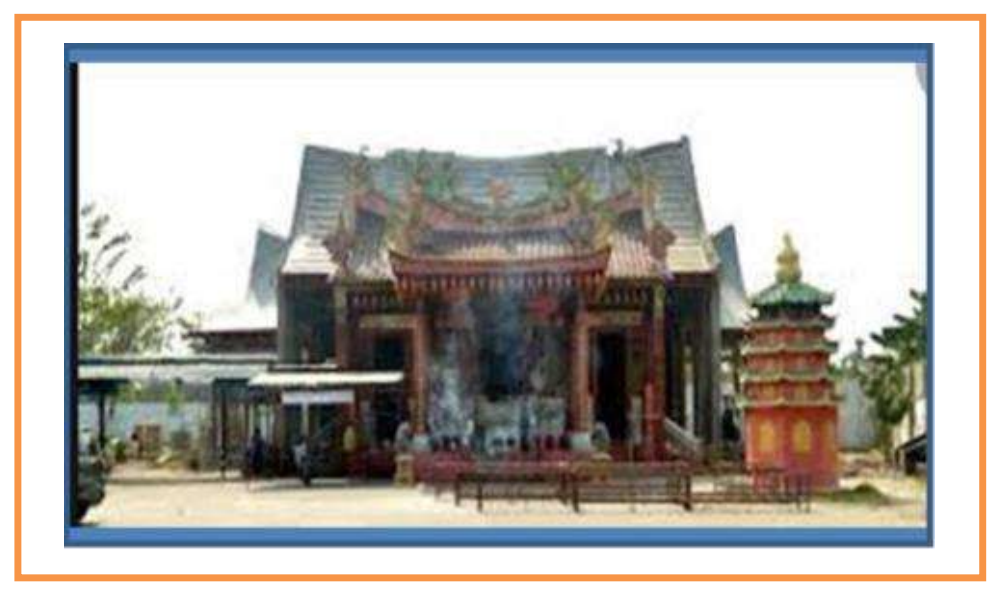

Figure 4. Medan Labuhan Malay House 
The Tri Dharma Temple is said to be the oldest building in Labuhan. According to local residents, this temple was founded by the Fujian community who built a settlement in Labuhan. The exact year of the establishment of this temple is not known, but the permission to build this temple shows that it was a temporary residence and was given the authority of the Sultan of Deli to trade in Labuhan. The shape of this pagoda is still maintained by the manager as it was and is well preserved.

\section{Mesjid Raya Labuhan}

This mosque is a building from the time of Sultan Deli VII Osman Perkasa Alam (1824-1854), the father of Sultan Mahmud. Sultan Osman Perkasa Alam himself died in 1858 he was buried in the backyard of the mosque. This mosque carried out several renovations in 1870-1872 by Sultan Deli VIII Mahmud Al Rasyid led by a German architect, GD Langereis, then in 1972 it was initiated by Deli Maatschappij, a joint venture company of the Sultanate of Deli and the Netherlands, in 1964 the restoration was carried out by T. Burhanuddin, President Director of PT Tembakau Deli II and 1977-1992.

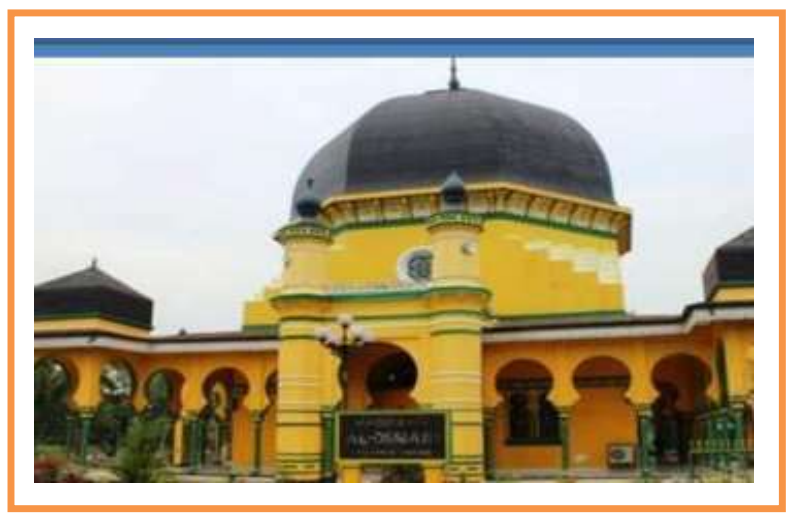

Figure 5. Medan Labuhan Al Osmani Mosque

\section{Ex Customs Building}

This building is one of the historical assets of how the movement of customs and import exports that used to enter the Malay plain of Deli with its archiving system. The office building is considered important as a witness about the trade trips that enter the city of Medan and its surroundings.

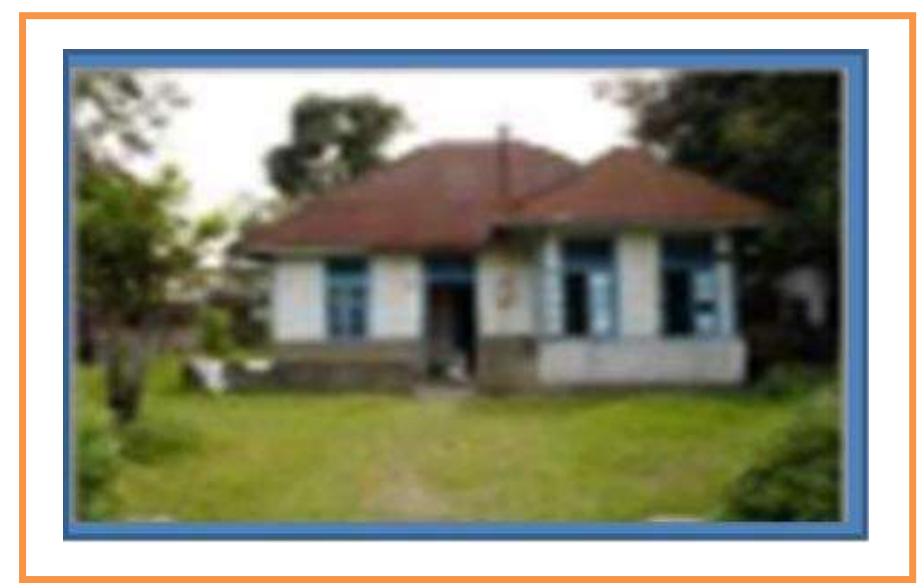

Figure 6. Ex Customs Building for Medan Labuhan 


\section{Belawan Railway Station}

Labuhan Railway Station was inaugurated on 16 Februari 1888 is one of the stations established by Deli Spoorweg Maatschappij (Dutch-owned railway company) as a station to support the transportation of plantation products which are also owned by the Dutch.

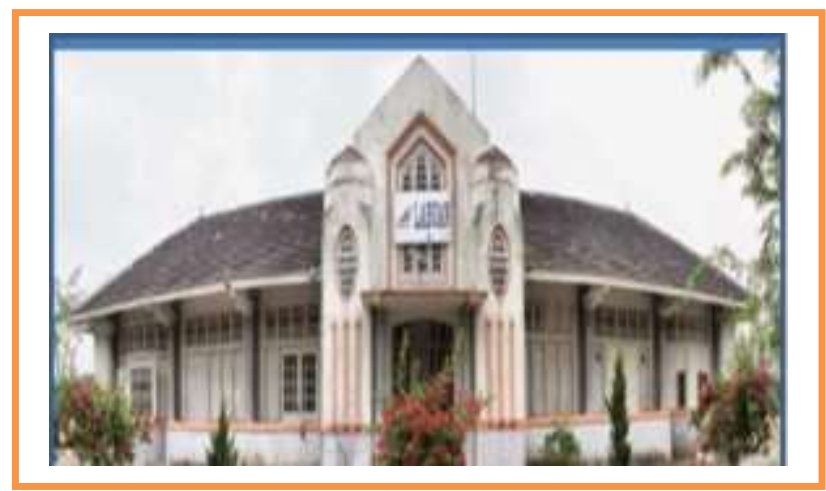

Figure 7. Medan Labuhan Train Station

The guidance process for these historical assets has also been stated in the RDTR (Detailed City Spatial Plan, especially for Medan Labuhan) Maintaining existing train stations as passenger terminals and developing new stations for loading and unloading goods, which are located integrated with bus terminals, container terminals (dry port), goods terminal and warehousing area in the northern part of the city (Medan Labuhan and Belawan Districts). As for the assets of houses of worship and history, they are still controlled by the Malay kingdom and the Chines in Medan Labuhan.

6. Housing and Warehousing area which was originally DSM (Deli Spoorweg Maatsehappij) in Pulo Brayan

Development of a passenger port (TOD) integrated with a railway station and warehousing, international container seaports, industrial estates, warehousing and expedition, Export Processing Zone (EPZ), and residential centers.

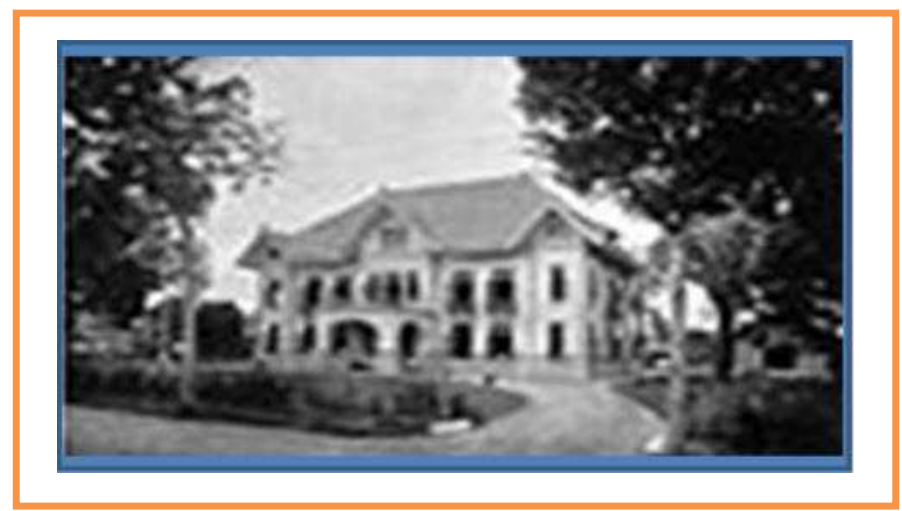

Figure 8. Deli Spoorweg Maatschappij, N.V. (DSM)

7. The Maimun Palace area which includes Medan City Grand Mosque, Maimun Palace and Sri Deli Park.

The Maimun Palace area is a historical icon and an icon of the Deli Malay tribe in Medan City. The heyday of the Deli Malay tribe is marked by the development and existence of Malay cultural assets with the solidity of the Deli Malay palace, namely the Maimun Palace. 

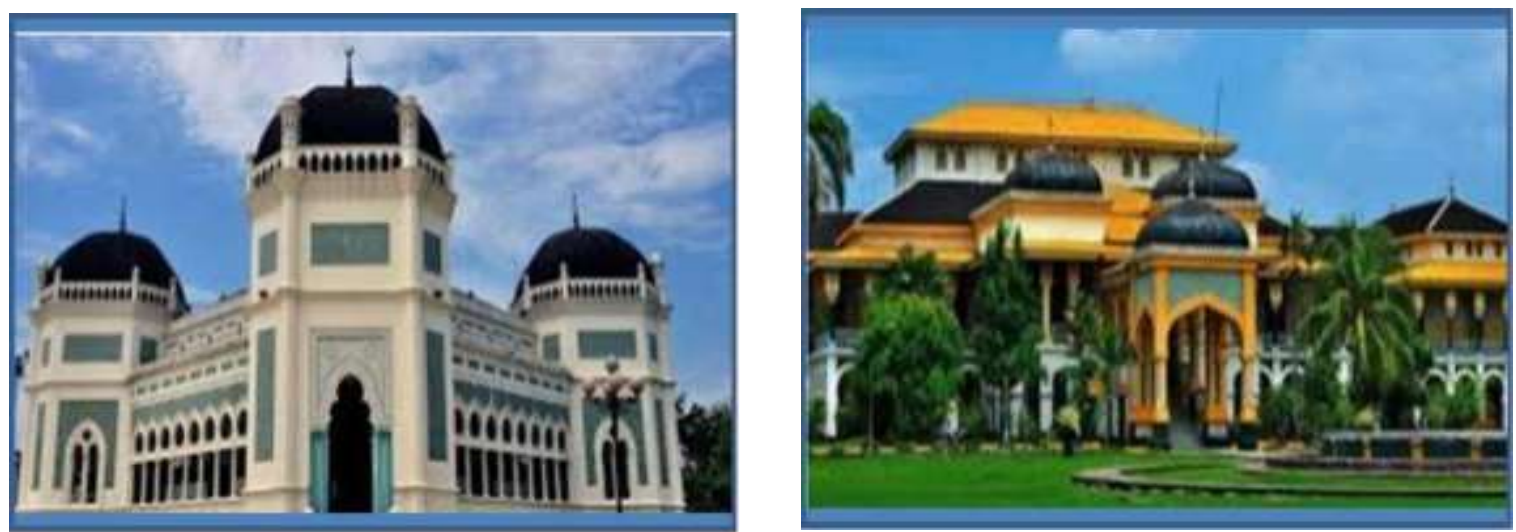

Figure 9. Medan City Grand Mosque and Maimun Palace

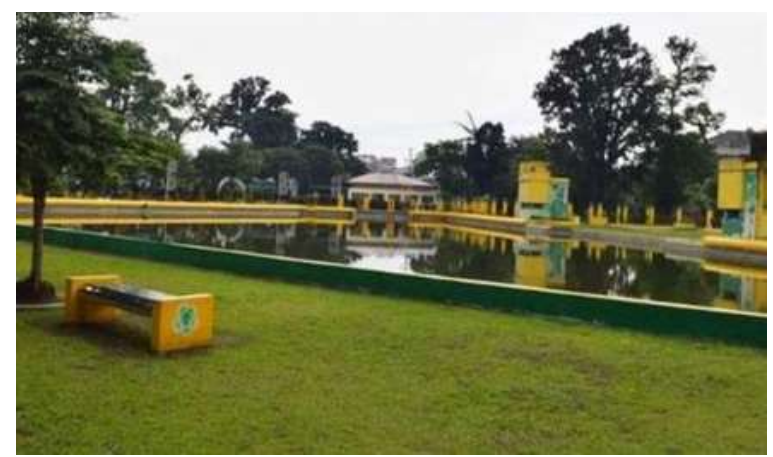

Figure 10. Taman Sri Deli Medan

One of the coaching processes carried out by the Medan City Government is also the development of a mass transportation facility system to support Medan City as a Metropolitan City, which includes bus lines, busways, monorails, LRT or heavy rail. At this time, the City vehicles that cross have also been determined, including the City of Mebidang vehicles.

Arrangement and other guidance such as parking lots Development of off-street parking systems and curbside parking arrangements and restrictions (on street parking). However, the maimun palace is a cultural and ancestral asset of the Malay Deli Sultanate and it is still vulnerable to control which is the authority of the Sultanate. Thus, the Medan City government also has certain limitations for the development process. The development process includes transportation routes related to mass activities.

\section{Kampung Keling area;}

The early 19th century, many people from Tamil India came from their country to Indonesia to become workers, namely as tobacco plantation workers. However, over time, more and more Tamil Indians are working in Medan. As time went by, not only Indian Tamils came to Medan, but Cheyttar Indians and Punjabi also came to try their luck in Medan.

\section{Kesawan Area}

Kesawan is the name of an area in West Medan District. This area is an area filled with historical buildings and Jalan Ahmad Yani which is in this area is the oldest street in Medan. In the early 2000s, the Kesawan area was used as a bustling hawker center at night called 
Kesawan Square. Jalan Ahmad Yani is closed at night and turned into an open culinary center. After it was closed, a hawker center was built as a replacement at Merdeka Square, in front of the Bank Indonesia building which was named Merdeka Walk.
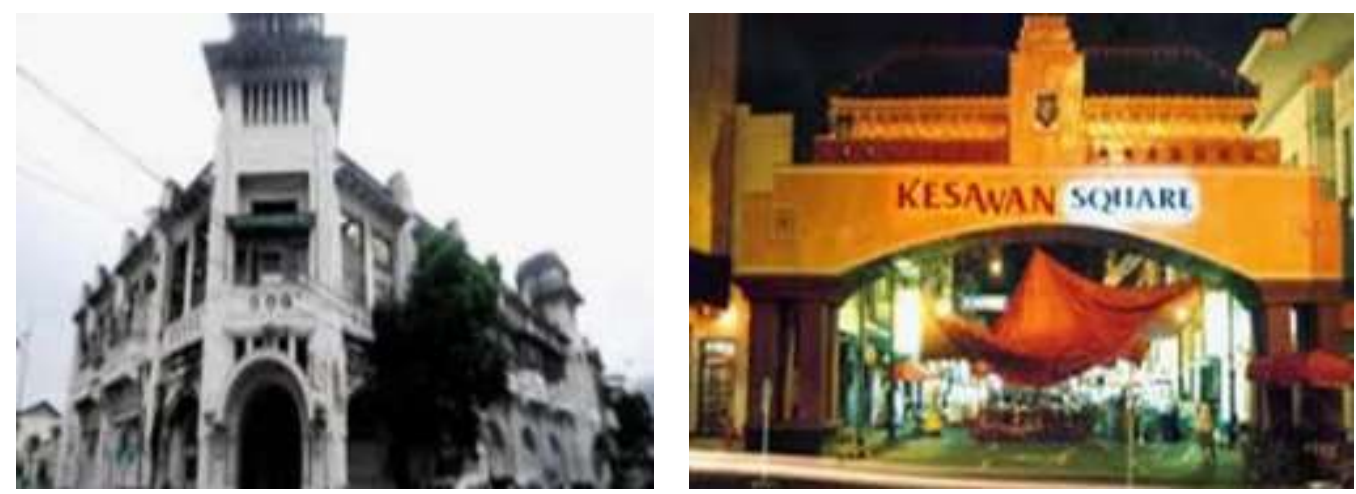

Figure 11. Kesawan Medan

Kesawan is a downtown area which is currently one of the economic points in the city of Medan. The Kesawan area is currently being built as a culinary hawker center located around the independent field. Beside RDTR, there is a Green Open Space / RTH (Playground). The Medan City Government is trying to build without losing the characteristic of Kesawan as a tourist center as well. One of the coaching carried out by the Medan City Government includes.

\subsection{Discussion}

The process of this analysis, the researcher tries to find several indicators that can be one of the reinforcements in this study by analyzing the indicators and performance variables in the study. With IFAS and EFAS analysis in SWOT.

Table 1. IFAS Analysis

\begin{tabular}{|c|c|c|c|}
\hline Strengths & Rating & Quality & Score \\
\hline Government regulations & 3.71 & 0.12 & 0.44 \\
\hline $\begin{array}{l}\text { About the 2010-2030 Medan City RTRW and } \\
\text { city RDTR }\end{array}$ & 2.43 & 0.12 & 0.29 \\
\hline Community efforts in maintaining regional assets & 2.86 & 0.09 & 0.26 \\
\hline Public transportation facilities & 2.57 & 0.10 & 0.26 \\
\hline \multicolumn{4}{|l|}{ Weaknesses } \\
\hline $\begin{array}{l}\text { Physical cultural values, for example: heritage } \\
\text { buildings are neglected }\end{array}$ & 3.71 & 0.13 & 0.49 \\
\hline $\begin{array}{l}\text { Low livelihood, community groups involved in } \\
\text { the development of the Area }\end{array}$ & 3.14 & 0.15 & 0.48 \\
\hline $\begin{array}{l}\text { Availability of capital in local economic } \\
\text { development and job creation is still low }\end{array}$ & 2.14 & 0.12 & 0.26 \\
\hline
\end{tabular}

Source: Researcher Analysis 2020 
Table 2. EFAS Analysis

\begin{tabular}{|c|c|c|c|}
\hline Opportunity & Rating & Quality & Score \\
\hline Quality and service quality, tourist attraction & 3.86 & 0.16 & 0.63 \\
\hline The physical condition of history and folklore & 3.71 & 0.13 & 0.49 \\
\hline $\begin{array}{l}\text { Local product development and local historical } \\
\text { value }\end{array}$ & 3.71 & 0.12 & 0.46 \\
\hline $\begin{array}{l}\text { Regional development through cooperation with } \\
\text { the government and private sector }\end{array}$ & 3.71 & 0.12 & 0.26 \\
\hline \multicolumn{4}{|l|}{ Threats } \\
\hline Historical building maintenance costs & 3.86 & 0.16 & 0.63 \\
\hline $\begin{array}{l}\text { The level of tourist satisfaction and purchasing } \\
\text { power }\end{array}$ & 3.17 & 0.12 & 0.26 \\
\hline Ancestral asset governance management & 3.14 & 0.15 & 0.48 \\
\hline Local asset development & 3.14 & 0.15 & 0.48 \\
\hline
\end{tabular}

Source: Researcher Analysis 2020

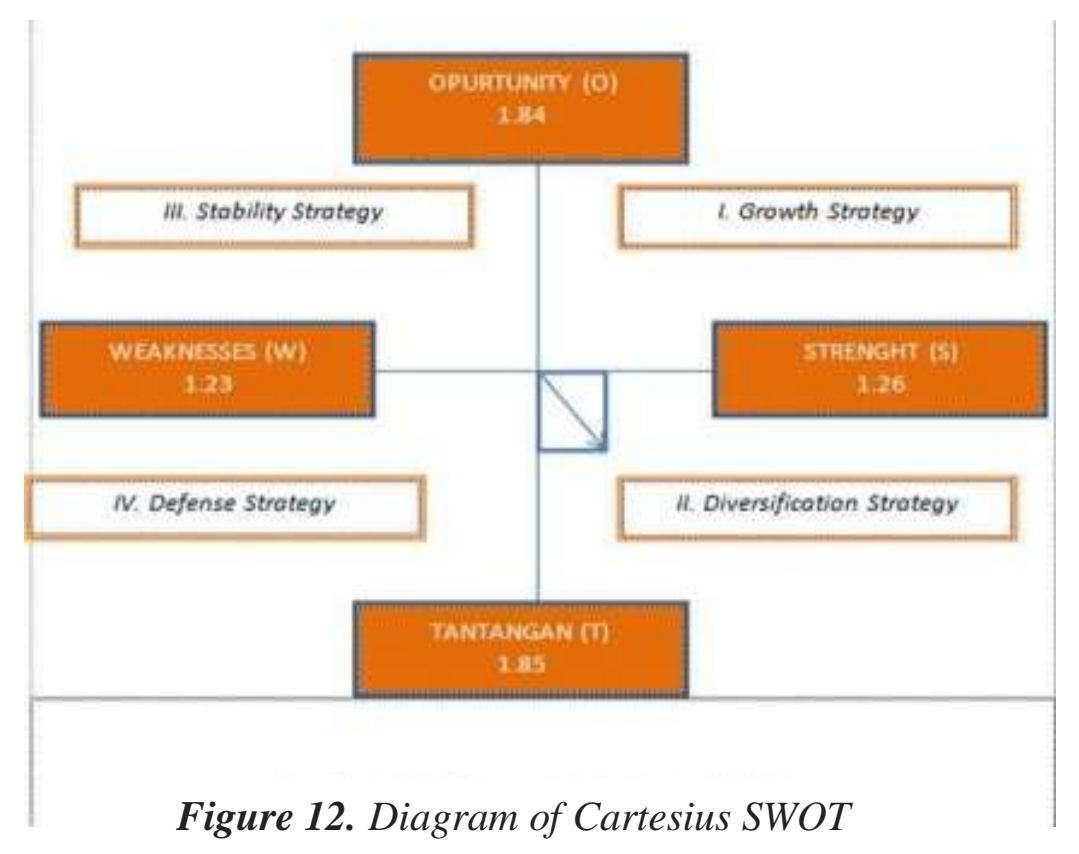

\section{Conclusion}

Based on the results of the analysis above, the IFAS table is obtained with a Strength score of 1.26 while the weakness factor is 1.23 , while the Opportunity EFAS table has a total score of 1.84 while the Challenge is 1.85 . So based on the total score obtained from the above analysis. The Kawasasan Strategic Kota (KSK) in the Socio-Cultural Sector is experiencing a Diversification Strategy, which means that the City Strategic Area (KSK) in the SocioCultural Sector has the potential to be developed but there are still things that need to be prepared strategically and improved management by the Medan City Government. Because opportunities and challenges have the potential to be developed. The Medan City Government must also be careful with seeing the challenges ahead because the development process and cultural assets have historical strength and legal legality in their ownership. 


\section{References}

Anonim. 2009. Kamus Penataan Ruang Edisi 2. Jakarta. Direktorat Jendral Penataan Ruang DPU.

Bintarto, R. 1983. Interaksi Kota-Desa dan Permasalahannya. Yogyakarta: Ghalia Indonesia.

Bo'do, S., et al (2019). Social Media, Public Sphere and Movement Discussion of Urban Farming in Indonesia. Budapest International Research and Critics Institute-Journal (BIRCI-Journal), P. 250-261.

Delango, M.W. (2019). The Causes and Consequences of Rural-urban Migration: The Case of Wolaita Sodo Town Merhal Sub-City. Budapest International Research and Critics Institute-Journal (BIRCI-Journal), P. 99-114.

Laporan Akhir Revisi Rencana Tata Ruang Wilayah (RTRW) Kota Medan Tahun 2010-2030. Badan Perencanaan Pembangunan Kota Medan

Nurhidayani, Yani. 2013. Metode Penelitian Kualitatif, 12 April 2013. [Online]. Tersedia di: http://yaniqiute.wordpress.com /2013/04/12/metode- penelitian- kualitatif/. Diakses pada 12 Juli 2013.

Tarigan, Robinson. 2004. Perencanaan Pembangunan Wilayah. Jakarta: Bumi Aksara.

Undang-Undang Republik Indonesia Nomor 26Tahun 2007 tentang Penatan Ruang.

Wijanarka. 2003. Teori Desain Kawasan Bersejarah (Suatu Dasar Mewujudkan Desain Pelestarian dan Pembangunan Kawasan Bersejarah Semarang Semarang sebagai Obyek Kajian). Palangkaraya: Teknik Arsitektur Universitas Palangkaraya.

Wijanarka. 2007. Semarang Tempo Dulu Ombak.Yogyakarta. Yunus, Hadi Sabari. 2000. Struktur Tata Ruang Kota. Yogyakarta: Pustaka Pelajar. 